\title{
BDKRB2 wt Allele
}

National Cancer Institute

\section{Source}

National Cancer Institute. BDKRB2 wt Allele. NCI Thesaurus. Code C51428.

Human BDKRB2 wild-type allele is located within 14q32.1-q32.2 and is approximately 40 $\mathrm{kb}$ in length. This allele, which encodes B2 bradykinin receptor protein, plays a role in the initiation of several different biological responses including, vasodilation, edema, smooth muscle spasm and pain fiber stimulation. 